\title{
THE AMINO ACID SEQUENCE OF PROTEINASE A INHIBITOR 3 FROM BAKER'S YEAST
}

\author{
by \\ KIRSTEN BIEDERMANN, UMBERTO MONTALI ${ }^{1}$, BRIAN MARTIN², \\ IB SVENDSEN and MARTIN OTTESEN
}

Department of Chemistry, Carlsberg Laboratory, Gamle Carlsberg Vej 10, DK-2500 Copenhagen, Valby

1 Permanent address: Institute of Biological Chemistry, University of Pisa, Via Roma 55, Pisa. Italy

2Permanent address: Max-Planck-Institut, Rheinlanddamm 201, D-4600 Dortmund I, W. Germany

Keywords: Protease inhibitor, proteinase A, yeast, amino acid sequence

The amino acid sequence of yeast proteinase A inhibitor 3 (IA3) was determined to be Ac-Met-Asn-Thr-AspGln-Gln-Lys-Val-Ser-Glu-Ile-Phe-Gln-Ser-Ser-Lys-Glu-Lys-Leu-Gln-Gly-Asp-Ala-Lys-Val-Val-Ser-Asp-AlaPhe-Lys-Lys-Met-Ala-Ser-Gln-Asp-Lys -Asp-Gly-Lys -Thr-Thr-Asp-Ala-Asp-Glu-Ser-Glu-Lys-His-Asn-TyrGln-Glu-Gln-Tyr-Asn-Lys-Leu-Lys-Gly-Ala-Gly-His-Lys-Lys-Glu.

This structure was established by automated Edman degradation of peptides derived from cyanogen bromide fragmentation and enzymatic digestion with $\mathrm{S}$. aureus V8 protease and chymotrypsin. High pressure liquid chromatography was used to separate the peptides from the different cleavage reactions. The cyanogen fragment residues $2-33$ contained the inhibitory activity.

\section{INTRODUCTION}

Baker's yeast contains two endopeptidases, proteinases A and B (7), and several inhibitors, specific for these proteinases (3). The inhibitors so far characterized are relatively small, heat and acid resistant proteins containing no arginine, tryptophan, and cysteine $(15,19,2)$.
The amino acid sequence of two proteinase $B$ inhibitors, $I^{\mathrm{B}} \mathrm{I}$ and $\mathrm{I}^{\mathrm{B}} 2$, has recently been determined $(12,13)$. They both contain 74 amino acid residues and only two amino acid residues differ in location when comparing their sequences. In both $\mathrm{I}^{\mathrm{B}} 1$ and $\mathrm{I}^{\mathrm{B}} 2$ it was observed that the inhibitory activity disappeared when 4

Abbreviations: $\mathrm{I}^{\mathrm{A}} 3=$ proteinase $\mathrm{A}$ inhibitor 3 in nomenclature of NUNEZ DE CASTRO and Hol.zer (15), HPLC $=$ high pressure liquid chromatography, TEAP $=$ triethylammoniumphosphate, $\mathrm{PITC}=$ phenylisothiocyanate, $\mathrm{PTH}=$ phenylthiohydantoin . 
amino acid residues were removed from the $\mathrm{C}$ terminal part of these molecules (11).

Four species of proteinase A inhibitors have been described in the literature (19). Two of these, $\mathrm{I}^{\mathrm{A}} 2$ and $\mathrm{I}^{\mathrm{A}} 3$, have been isolated and partly characterized $(15,19)$. In the present report the amino acid sequence of one of these inhibitors, $I^{A} 3$, is presented. In spite of the similarities in size and heat resistance it shows no homology with the proteinase B inhibitors.

\section{MATERIALS AND METHODS}

\subsection{Materials}

Baker's yeast was obtained from De danske Spritfabrikker, Copenhagen. SP-Sephadex C-25 and QAE-Sephadex A-25 were from Pharmacia, Uppsala, Sweden. Ampholines for isoelectric focusing were from LKB-Produkter $\mathrm{AB}$, Bromma, Sweden. Biogel P-6 was a product of Bio-Rad Laboratories, Richmond, California, U.S.A.

S. aureus V8 protease originated from Miles Laboratories Ltd., England, and chymotrypsin was purchased from Novo Industri A/S, Copenhagen. Triethylamin was from Ferak, Berlin, West Germany and acetonitrile, HPLC grade SS, from Rathburn Chemicals Ltd., Walkesburn, Scotland. Cyanogen bromide was from Fluka AG, Buchs, Switzerland and N-acetylmethionine amide from Bachem Feinchemikalien AG, Bubendorf, Switzerland. DL-homoserine was from Calbiochem, Los Angeles, U.S.A.

All chemicals used for sequence determinations were as described by JOHANSEN et al. (9).

\subsection{Methods}

\subsubsection{Purification of $I^{A} 3$}

IA3 was isolated from baker's yeast essentially as described by Nunez de CASTro and Holzer (15). The first purification step which consists of heating the yeast suspension to $100^{\circ} \mathrm{C}$ for 20 min followed by immediate cooling must be performed carefully to prevent loss of inhibitor activity. Following centrifugation, the extract was subjected to repeated chromatography on SP-Sephadex C-25 (step 2 and 3 in ref. 15) and QAE-Sephadex A-25 (step 4 and 5 in ref. 15).

Analytical disc gel electrophoresis with sodium dodecylsulfate (21) of this inhibitor prepa- ration showed that two bands were present, a minor band with a molecular weight of about 13,500 and a major band with a molecular weight of about 7,700. Analytical isoelectric focusing on polyacrylamide gel plates (26) also showed the presence of two bands, a minor band with an isoelectric point (pI) of 6.85 and a major band with $\mathrm{pl}$ of 6.6. The two protein bands were isolated from the mixture by preparative isoelectric focusing in granulated gels (25) and tested for inhibitor A activity. The band with a pI of 6.6 contained all the inhibitor activity and was shown to be homogeneous by analytical disc gel electrophoresis in sodium dodecylsulfate with a mobility corresponding to an apparent molecular weight of 7,700.

Since only slight additional purification was evident after the first QAE-Sephadex chromatography, the second QAE-Sephadex step was replaced by preparative isoelectric focusing in an LKB 8101 column (24) with a $\mathrm{pH}$ gradient from 5 to 8 stabilized by a sucrose density gradient at $10^{\circ} \mathrm{C}$. The $\mathrm{pH}$ of the eluted fractions was measured at room temperature. The fractions containing the inhibitor A activity ( $\mathrm{pI}=6.6$ ) were separated from Ampholines and sucrose by dialysis against distilled water for 3 hours in Visking tubing $(10 \mathrm{~mm}$ flat width). When necessary, residual traces of Ampholines were removed from the inhibitor preparation by chromatography on a Biogel P-6 column $0.8 \mathrm{~cm}$ $\times 18 \mathrm{~cm}$ ) equilibrated and eluted with $30 \%$ acetic acid.

\subsubsection{Assay of $I^{A 3}$}

Proteinase A was prepared as described by SAHEKI and Holzer (18) and a trace contamination of carboxypeptidase $\mathrm{Y}$ in the preparation was removed by passing the solution over an affinity column (8). Proteinase A activity was determined according to the method of SAHEKI and Holzer (17) both during the preparation of the enzyme and for the evaluation of inhibitor $\mathrm{A}$ activity. A typical assay was as followed: $0.8 \mathrm{ml}$ of $1.2 \%$ hemoglobin in $0.1 \mathrm{~m}$-potassium lactate buffer $\mathrm{pH} 3.0$ was incubated with $0.1 \mathrm{ml}$ of proteinase A with or without inhibitor in 0.05 M-potassium lactate buffer $\mathrm{pH}$ 4.5. After 30 minutes $0.8 \mathrm{ml} 10.6 \%$ trichloroacetic acid solution was added and after another 30 minutes 
the solution was centrifuged and the absorbance of the supernatant measured at $280 \mathrm{~nm}$.

Proteinase A inhibition by IA 3 has been examined by SAHEkı et al. (19). Since complete inhibition of proteinase $\mathrm{A}$ is not achieved at $\mathrm{pH} 3$ (compare Figure 6) only the initial linear part of the curve has been used for assay of inhibitory activity.

\subsection{Cyanogen bromide cleavage and enzymatic digestion}

In a typical experiment $8 \mathrm{mg}$ of cyanogen bromide was added to $1.0 \mathrm{mg} \mathrm{I} \mathrm{I}_{3}$ in one $\mathrm{ml}$ $70 \%$ formic acid. After incubation for 22 hours in the dark at room temperature the sample was purged for 2-3 hours with nitrogen, diluted with 10 volumes of distilled water and lyophilized. Amino acid analysis showed that $94 \%$ of the methionyl bonds were cleaved.

Digestion of IA3 with Staphylococcus aureus V8 protease was performed in ammonium bicarbonate buffer, $\mathrm{pH} 7.8$, in an attempt to restrict the cleavage to glutamic acid residues as described by Austin and Smith (1). Complete digestion was obtained by incubating $660 \mu \mathrm{g}$ of IA3 with $20 \mu \mathrm{g}$ enzyme in $200 \mu \mathrm{l} 0.05 \mathrm{M}$-ammonium bicarbonate buffer, $\mathrm{pH} 7.8$, overnight at $40^{\circ} \mathrm{C}$. Limited digestion was performed with $375 \mu \mathrm{g} \mathrm{I}$ A 3 in $125 \mu \mathrm{l}$ of the same buffer and $4 \mu \mathrm{g}$ enzyme. After one hour of incubation at $30^{\circ} \mathrm{C}$ the reaction was terminated by adding $6 \mu l 2 \mathrm{M}$ $\mathrm{HCl}$ and the digest was lyophilized.

Two mg of IA3 was digested with $11 \mu \mathrm{g}$ of chymotrypsin at $\mathrm{pH} \quad 8.0$ and $30^{\circ} \mathrm{C}$ in a Radiometer TTT $60 \mathrm{pH}$-stat using $0.011 \mathrm{~m}$ $\mathrm{KOH}$ as titrant. After the consumption of $54 \mu \mathrm{l}$ of base $\left(2.3 \mathrm{eq} \cdot \mathrm{mol}^{-1}\right)$ the digestion was terminated by adding $1 \%$ phosphoric acid.

\subsection{Fractionation of peptides by high pressure liquid chromatography (HPLC)}

Reverse phase HPLC with triethyl ammonium phosphate (TEAP) buffer as introduced by RIVIER (16) was used to separate mixtures of peptide fragments.

The peptide mixture resulting from cyanogen bromide treatment was dissolved in $300 \mu 10.05$ M-TEAP buffer $\mathrm{pH} 3.0$ and chromatographed in portions of 60-100 $\mu \mathrm{l}$ using a Waters Associates liquid chromatographic system equipped with a variable UV-detector Model 450, a solvent programmer Model 660 and a $\mu$ Bondapack C- 18 column $(0.45 \times 30 \mathrm{~cm})$. The buffers A: $0.05 \mathrm{M}$ TEAP, pH 3.0, and B: $0.05 \mathrm{M}$-TEAP, pH 3.0. in $80 \%$ acetonitrile were used to form a linear gradient from $0 \% \mathrm{~B}$ to $80 \% \mathrm{~B}$ over 15 min with a flow rate of $1.5 \mathrm{ml}$ per min. The absorption was monitored at $210 \mathrm{~nm}$ and recorded on a 3380 A Hewlett Packard integrator. The eluted peptides were collected manually as soon as they appeared on the chromatogram. The delay time from detector to collection was 16 seconds. The phosphate ions in the collected samples were removed by precipitation with barium acetate using a molar ratio of TEAP: barium acetate of 0.9:1. The samples containing the barium phosphate precipitate were lyophilized to remove acetonitrile and triethylammonium acetate, resuspended in water and filtered on a Millipore filter type $\mathrm{HA}$ with pore size $0.45 \mu \mathrm{m}$. The precipitate was washed several times with water and the washings lyophilized together with the filtrate. The yield of peptides after isolation and phosphate precipitation was approximately $40 \%$ of the quantity applied to the column.

The chymotryptic peptide mixture was chromatographed in the same system using a LiChrosorb $5 \mu \mathrm{m}, \mathrm{RP}-18$ column $(0.39 \times 25$ $\mathrm{cm}$ ) with samples ranging from 100 to $200 \mu \mathrm{l}$ of peptides, approx. $1.0 \mathrm{mg} \cdot \mathrm{ml}^{-1}$. The peptides were collected as described.

The HPLC columns were frequently cleaned to remove adherent peptides and impurities. These were difficult to remove with pure A or B buffers alone and it was found more effective to rinse the columns with a linear gradient of the buffers from $0 \% \mathrm{~B}$ to $100 \% \mathrm{~B}$ with a flow rate of $0.2 \mathrm{ml} \cdot \mathrm{min}^{-1}$ overnight or with $0.125 \%$ phosphoric acid, pH 2.15, and 100\% acetonitrile, alternately.

\subsection{Amino acid analysis}

Amino acid analyses were performed on a Durrum D-500 amino acid analyzer. The amino acid composition of $\mathrm{I}^{\mathrm{A}} 3$ was determined by hydrolysis of duplicate samples for 24, 48 and 96 hours in $5.7 \mathrm{M}-\mathrm{HCl}$ in evacuated and sealed tubes at $110^{\circ} \mathrm{C}$. The values for serine and threonine were obtained by extrapolating to zero 
time, and for valine and isoleucine the values after 96 hours of hydrolyses were used. The amino acid composition of peptide fragments were obtained from samples hydrolyzed 24 hours and the values are uncorrected. All results are expressed as molar ratios and concentrations of the inhibitor and peptides are based on amino acid analysis.

\subsection{Amino acid sequence determination}

Automatic sequence determinations were made with a Beckman model $890 \mathrm{C}$ liquid phase sequencer according to the method of EDMAN and BeGG (4). The procedure used has been described in detail by JoHANSEN et al. (9). All samples were applied to the cup dissolved in $30 \%$ acetic acid and dried using the Beckman sample application subroutine program 02772 . Polybrene $\left(100 \mu \mathrm{l}\right.$ of a solution $30 \mathrm{mg} \cdot \mathrm{ml}^{-1}$ in $\mathrm{H}_{2} \mathrm{O}$ ) was added to the cup to aid retention of the peptide film for all peptides sequenced. The repetitive yields were for most of the runs between $94 \%$ and $95 \%$.

Identification of PTH-amino acids was made by HPLC using a Hewlett Packard chromatograph, Model 1084B as described by SvendSEN et al. (22). Additional information was obtained from thin layer chromatography on polyamide sheets according to the method of KULBE (10).

\subsection{Peptide nomenclature}

The cyanogen bromide fragments are designated F-1, F-2 and F-3 according to the order in which they occur in the inhibitor starting from the N-terminal end. Similarly, the peptides resulting from cleavage with chymotrypsin are designated C-1, C-2 etc. up to C-6. The sequenced peptides from digestion with $\mathrm{S}$. aureus protease are designated with SP.

\section{RESULTS}

The IA3 isolated from baker's yeast had an isoelectric point of $\mathrm{pH} 6.6$ as determined by isoelectric focusing in a sucrose gradient (Figure 1). The amino acid composition (Table I) is close to the one previously published by NUNEZ DE CASTRO and Holzer (15), but there is a slightly

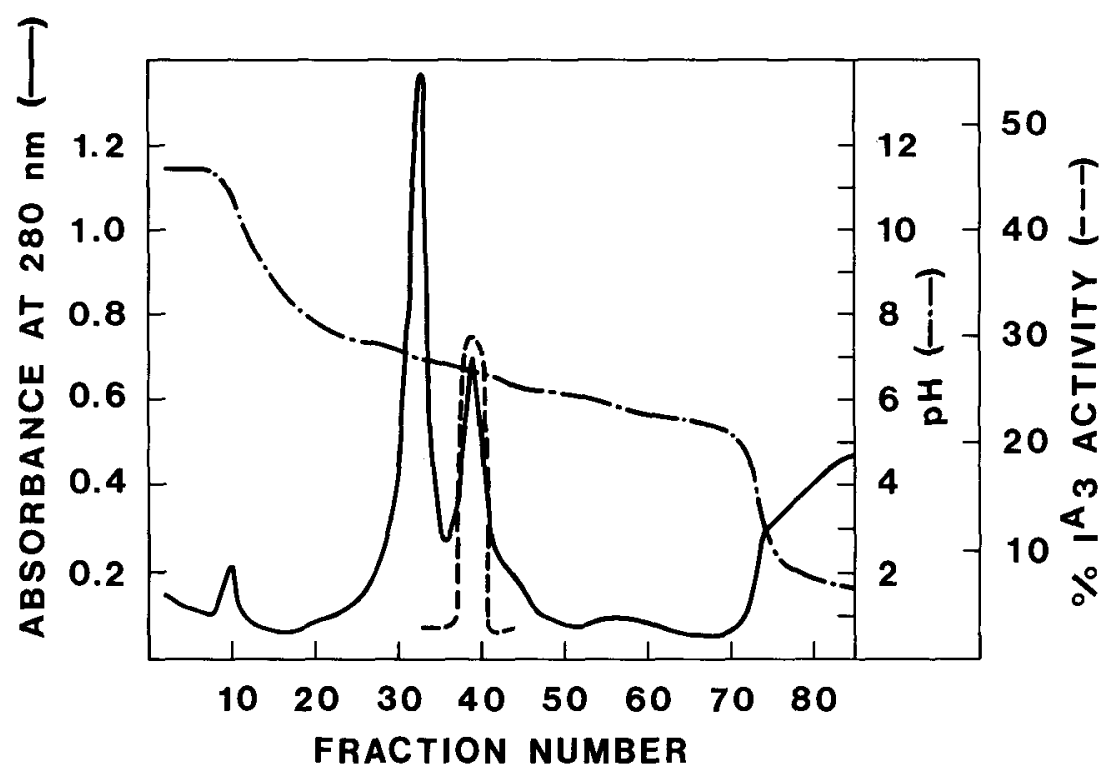

Figure 1. Isoelectric focusing of about $3 \mathrm{mg} \mathrm{I}^{\mathrm{A}} 3$ after the first QAE-Sephadex chromatography.

LKB 8101 column was used with a pH-gradient of equal amounts of LKB-Ampholines pH 5-8 and pH 6-8. A gradient from $0-50 \% \mathrm{w} / \mathrm{v}$ sucrose was used to stabilize the $\mathrm{pH}$ gradient and the column was thermostated at $10^{\circ} \mathrm{C}$. After 45 hours of focusing, the content was collected in fractions of $750 \mu \mathrm{l}$. The $\mathrm{pH}$ and absorbance at $280 \mathrm{~nm}$ was measured on every second fraction at room temperature. Inhibitor activity in the protein peaks was measured as \% of total remaining activity as described in section 2.2.2. 
Table I.

Amino acid composition of $\mathrm{I}^{\mathrm{A}} 3$ ( $\mathrm{mol}$ of residue/mol)

\begin{tabular}{lccc}
\hline & $\begin{array}{c}\text { Average } \\
\left.\text { values }^{\mathrm{a}}\right)\end{array}$ & $\begin{array}{c}\text { Sequence } \\
\text { values }^{\mathrm{b})}\end{array}$ & $\begin{array}{c}\text { Literature } \\
\text { values }^{\mathrm{c}}\end{array}$ \\
\hline Asp & 10.5 & 10 & 10 \\
Thr & $3.0^{\mathrm{d})}$ & 3 & 3 \\
Ser & $5.8 \mathrm{~d})$ & 6 & 6 \\
Glu & 13.3 & 13 & 13 \\
Gly & 4.4 & 4 & 5 \\
Ala & 4.8 & 5 & 5 \\
Val & $2.8 \mathrm{e})$ & 3 & 2 \\
Met & 1.9 & 2 & 2 \\
Ile & $0.9 \mathrm{e})$ & 1 & 1 \\
Leu & 1.9 & 2 & 2 \\
Tyr & 1.7 & 2 & 2 \\
Phe & 1.9 & 2 & 2 \\
His & 1.9 & 2 & 2 \\
Lys & 13.1 & 13 & 13 \\
\hline Total number & & & \\
of residues & & 68 & 68 \\
\hline
\end{tabular}

a) Average values from amino acid analyses of duplicate samples of IA3 hydrolyzed 24, 48 and 96 hours. b) Amino acid composition calculated from the determined sequence. c) Refers to NuNEZ DE CASTRo and Holzer (15). d) Extrapolated to zero time. e) Value after 96 hours hydrolysis.

higher content of valine and a lower glycine content. The composition is consistent with that of a peptide of 68 amino acid residues. Proline, tryptophan, cystine and arginine are lacking, while the content of polar amino acid residues is high.

An initial attempt to sequence $\mathrm{I}^{\mathrm{A}} 3$ from the $\mathrm{N}$ terminus failed due to the presence of a blocked amino acid residue and hence, initial fragmentation of the inhibitor was necessary. This was achieved by cyanogen bromide cleavage and by enzymatic degradation with $\mathbf{S}$. aureus protease and chymotrypsin, respectively.

\subsection{Cyanogen bromide peptides}

Cleavage of the two methionyl bonds in IA3 yielded three fragments, F-1, F-2 and F-3, which could be separated on a $\mu$ Bondapack C-18 HPLC column (Figure 2). Peak 1 contained besides F-1 byproducts and impurities from the cyanogen bromide reaction, while peak 2 and peak 3

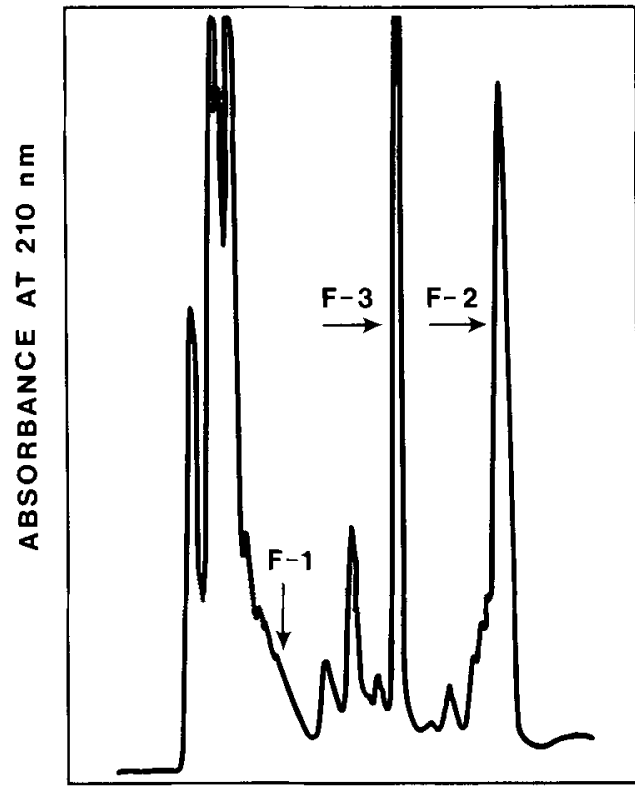

\section{MINUTES}

Figure 2. Elution profile from HPLC (column: $\mu$ Bondapack C-18, $0.45 \times 30 \mathrm{~cm}$ ) of $0.23 \mathrm{mg}$ of cyanogen bromide treated IA3.

Buffer A: 0.05 m-TEAP, pH 3.0, and buffer B: $0.05 \mathrm{M}$-TEAP, pH 3.0 , in $80 \%$ acetonitrile. A linear gradient over $15 \mathrm{~min}$ from $0 \%$ B to $80 \%$ B was used with a flow rate of $1.5 \mathrm{ml} \cdot$ minutes $^{-1}$. The eluted peptides were located by monitoring the absorbance at $210 \mathrm{~nm}$ and collected manually.

corresponded to F-3 and F-2, respectively. The amino acid analyses of these two peaks (Table II) showed that F-3 consisted of 35 amino acid residues and F-2 consisted of 32 amino acid residues including one residue of methionine determined as homoserine plus homoserine lactone.

65 nmoles of F-2 were placed in the sequencer and 20 steps of degradation were succesfully performed allowing the determination of the sequence from positions $2-21$ as indicated in Figure 4. From the start of the sequencing only 10 nmoles of the peptide had reacted, perhaps because the $\mathrm{N}$-terminal asparagine residue during the HPLC purification procedure used had been made partially resistant to Edman degradation.

60 nmoles of F-3 similarly analyzed through 34 steps of Edman degradation determined the sequence from positions 34-67 apart from the residue at position 65 (Figure 4).Parts of these 
K. Biedermann et al.: Proteinase A inhibitor 3

Table II.

Amino acid composition of peptide fragments (mol of residue/mol)

\begin{tabular}{lcccccccccccc}
\hline & \multicolumn{3}{c}{ Cyanogen bromide peptides } & \multicolumn{5}{c}{ Chymotrypsin peptides } \\
& \multicolumn{2}{c}{ F-3 } & \multicolumn{2}{c}{ F-2 } & \multicolumn{2}{c}{ C-1 } & \multicolumn{2}{c}{ C-2 } & C-6 \\
\hline Asp & 6.3 & $(6)$ & 4.3 & $(4)$ & 2.3 & $(2)$ & 2.7 & $(2)$ & 1.1 & $(1)$ \\
Thr & 1.9 & $(2)$ & 1.0 & $(1)$ & 1.1 & $(1)$ & 0.4 & & 0.1 & \\
Ser & 1.9 & $(2)$ & 3.9 & $(4)$ & 1.4 & $(1)$ & 2.8 & $(3)$ & 0.3 & \\
Glu & 7.1 & $(7)$ & 6.5 & $(6)$ & 3.4 & $(3)$ & 2.8 & $(3)$ & 1.2 & $(1)$ \\
Gly & 3.1 & $(3)$ & 1.1 & $(1)$ & 0.5 & & 2.1 & $(1)$ & 2.2 & $(2)$ \\
Ala & 3.0 & $(3)$ & 2.0 & $(2)$ & 0.3 & & 2.6 & $(2)$ & 1.1 & $(1)$ \\
Val & 0 & & 2.4 & $(3)$ & 1.0 & $(1)$ & 1.2 & $(2)$ & 0 & \\
Met & 0 & & 0 & $(1)$ & 0.8 & $(1)$ & 0 & & 0.1 & \\
Ile & 0 & & 0.9 & $(1)$ & 1.0 & $(1)$ & 0.3 & & 0.1 & \\
Leu & 1.0 & $(1)$ & 1.0 & $(1)$ & 0.2 & & 1.0 & $(1)$ & 1.0 & $(1)$ \\
Tyr & 1.8 & $(2)$ & 0 & & 0 & & 0.2 & & 0 & \\
Phe & 0 & & 1.8 & $(2)$ & 1.0 & $(1)$ & 0.9 & $(1)$ & 0 & \\
His & 1.9 & $(2)$ & 0.1 & & 0.1 & & 0.1 & & 0.9 & $(1)$ \\
Lys & 7.0 & $(7)$ & 5.7 & $(6)$ & 1.0 & $(1)$ & 2.5 & $(3)$ & 3.7 & $(4)$ \\
Homoserinea) & & & 1.0 & & & & & & & \\
\hline
\end{tabular}

Total number

of residues

35

32

12

18

11

Amino acid analysis of duplicate samples hydrolyzed 24 hours. a) Indicates homoserine and homoserine lactone.

sequences of the cyanogen bromide peptides were also observed in initial experiments where mixtures of F-2 and F-3 were sequenced together. In these cases the samples had been chromatographed on the less efficient Biogel P-6 column where the F-2 and F-3 peptides emerged as a single peak, although unequal amounts of the two peptides in the ascending and descending limbs of this peak permitted limited sequence analysis.

\subsection{S. aureus protease peptides}

The overlapping peptide connecting the F-2 and F-3 fragments was obtained from digestion of $I^{A} 3$ with $S$. aureus protease. Although the experimental conditions were chosen such that only peptide bonds involving glutamic acid were expected to be cleaved, an initial experiment with complete digestion (see section 2.3.) showed splitting at an aspartic acid residue. Therefore, the subsequent digestion was performed under milder conditions to suppress this undesired hydrolysis. The digestion mixture (48 nmoles) was applied directly to the sequencer cup since it was anticipated (see Figure 4) that the overlap- ping peptide would be contained in a long peptide fragment while other peptide fragments would be small and hence quickly washed out. This appeared to be correct because after five steps only two peptides were left. These were sequenced through 20 steps and provided the sequences from positions $11-30$ and 18-37, respectively, thus establishing the overlap between F-2 and F-3. It was hydrolysis of the Asp-Ala bond at position 28-29 which gave the undesired split during the complete $\mathbf{S}$. aureus digestion.

\subsection{C-terminal sequence of $I^{A} 3$}

To complete the sequence of the inhibitor attempts were made to degrade the peptide chain from the C-terminus by means of carboxypeptidases $\mathrm{Y}, \mathrm{A}$ and $\mathrm{B}$, but it was resistant to attack by all of these enzymes suggesting a blocked $\mathrm{C}$ terminal residue or a $\mathrm{C}$-terminal sequence unfavourable for enzymatic degradation.

The residue at position 65 in the C-terminus was, however, established as histidine by sequencing $30 \mathrm{nmol}$ of the chymotryptic peptide, C-6, isolated from a chymotryptic digest by HPLC (see section 3.5.). Again it was noticed 
that only a minor fraction of the peptide applied to the sequencer cup had reacted suggesting partial blocking of the $\mathrm{N}$-terminal asparagine during the HPLC purification procedure.

Comparison of the determined sequence of C-6, Figure 4, with the amino acid composition, Table II, shows that the only missing residue is a glutamic acid or glutamine residue.

\subsection{N-terminal residue of IA 3}

A comparison of the amino acid composition of total $\mathrm{IA}_{3}$ and the two cyanogen bromide fragments F-2 and F-3 indicated the N-terminal fragment $F-1$ to be a single methionine residue and because direct sequencing from the $\mathrm{N}$ terminus was not possible this methionine must be blocked.

The possibility of the $\mathrm{N}$-terminal being formyl methionine was unlikely because hydrolysis of $\mathrm{I}^{\mathrm{A}} 3$ in $0.5 \mathrm{M}$-methanolic hydrochloric acid as described by Shemmann et al. (20) failed to remove the blocking group.

Another possibility was that the blocking group might be an acetyl group and the $\mathrm{N}$ terminal residue to be identified after cyanogen bromide cleavage should then be $\mathrm{N}$-acetylhomoserine or $\mathrm{N}$-acetylhomoserine lactone (6).

As mentioned in section 3.1., the cyanogen bromide fragments of inhibitor A could be well separated on a HPLC column. The location of the small fragment F-I close to peak 1 in Figure 2 was confirmed by amino acid analysis of the collected fractions. The location of $\mathrm{N}$-acetylhomoserine and $\mathrm{N}$-acetylhomoserine lactone (generated from cyanogen bromide treatment of $\mathrm{N}$ acetylmethionine amide) is shown in Figure 3. $\mathrm{N}$-acetylmethionine amide, homoserine and homoserine lactone were similarly chromatographed and found to be located either after or before the $\mathrm{N}$-acetylhomoserine peak. The fragment F-1 from the cyanogen bromide treated $\mathrm{I}^{\mathrm{A}} 3$ cochromatographed with $\mathrm{N}$-acetylhomoserine and $\mathrm{N}$-acetylhomoserine lactone when a preparation of $30 \mathrm{nmol}$ cyanogen bromide treated IA3 (previously chromatographed on a Biogel P- 6 column) was passed through the same HPLC column. Amino acid analysis after acid hydrolysis confirmed the location of homoserine and homoserine lactone.

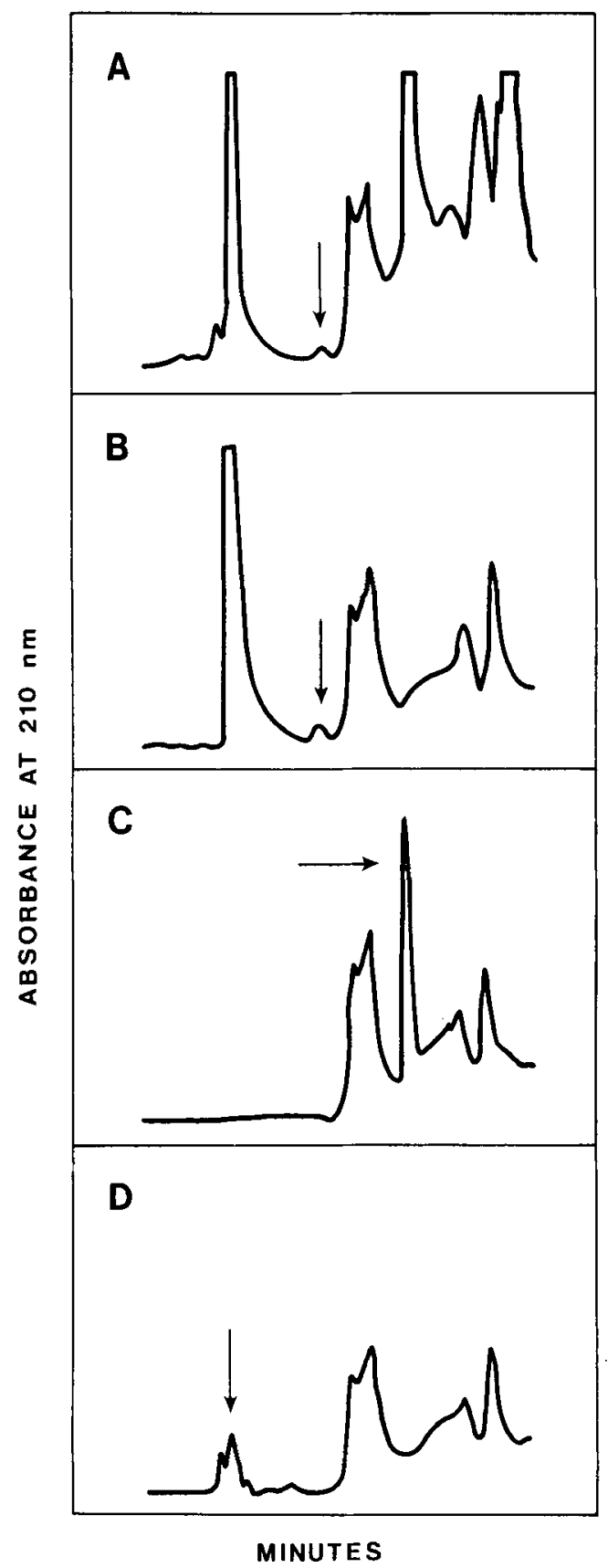

Figure 3. Elution profile from HPLC (column: LiChrosorb $5 \mu \mathrm{m}, \mathrm{RP}-18,0.45 \times 30 \mathrm{~cm}$ ) of A: 0.39 mg of cyanogen bromide treated $\mathrm{IA}^{\mathrm{A}}, \mathrm{B}: 10 \mu \mathrm{g}$ of $\mathrm{N}$ acetylhomoserine and $\mathrm{N}$-acetylhomoserine lactone. $\mathrm{C}: 10 \mu \mathrm{g}$ of $\mathrm{N}$-acetylmethionine amide and D: $40 \mu \mathrm{g}$ of homoserine containing some homoserine lactone. Elution conditions are as described for Figure 2. 
1

10

20

Ac-Met-Asn-Thr-Asp-GIn-GIn-Lys-Val-Ser-Glu-I le-Phe-GIn-Ser-Ser-Lys-Glu-Lys-Leu-G1n-

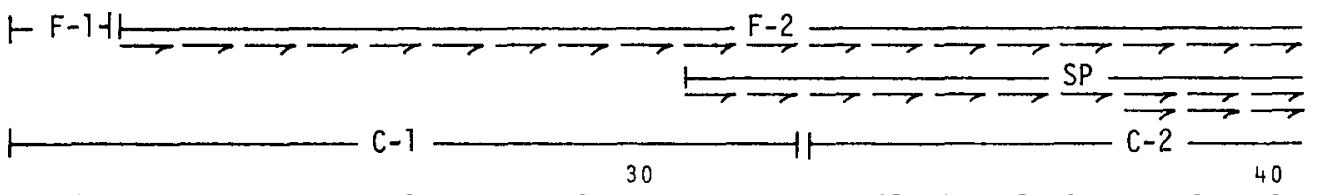

Gly-Asp-Ala-Lys-Val-Val-Ser-Asp-Ala-Phe-Lys-Lys-Met-Ala-Ser-Gln-Asp-Lys-Asp-Giy-

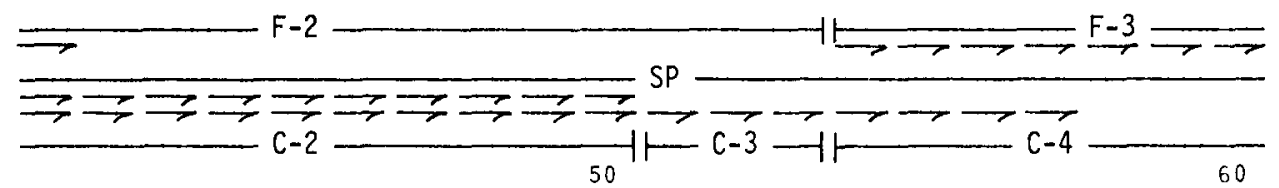

Lys-Thr-Thr-Asp-Ala-Asp-Glu-Ser-Glu-Lys-His-Asn-Tyr-Gln-Glu-Gln-Tyr-Asn-Lys-Leu-

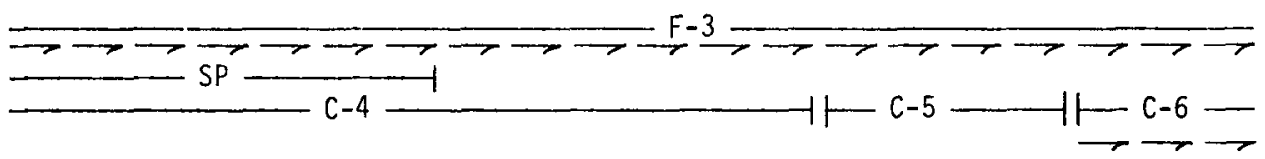

68

Lys-Gly-Ala-Gly-His-Lys-Lys-GTu

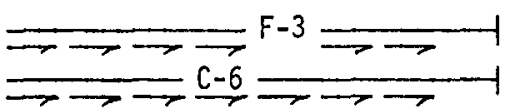

Figure 4. The complete amino acid sequence of inhibitor A based on the alignment of the sequenced peptides; $\rightarrow$, sequence established with automatic sequencer.

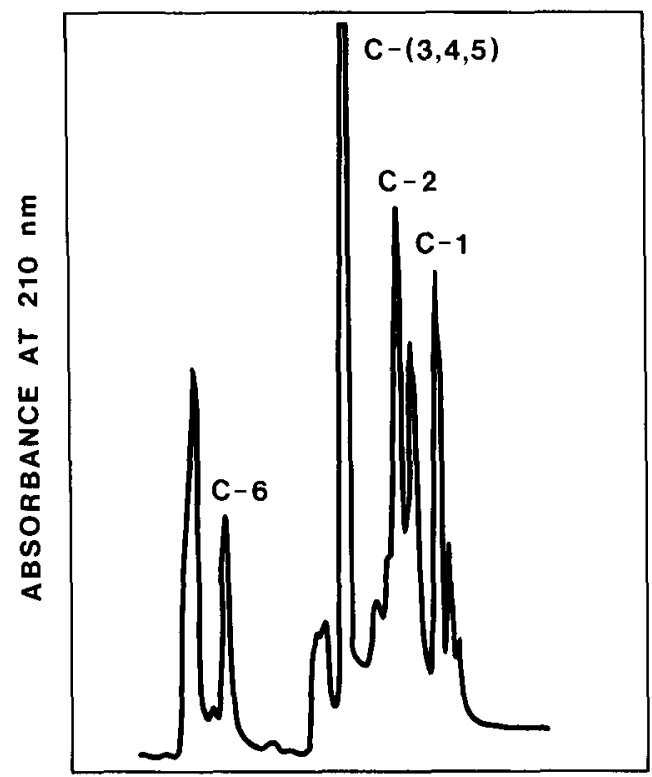

MINUTES

Figure 5. Elution profile from HPLC (column: LiChrosorb $5 \mu \mathrm{m}, \mathrm{RP}-18,0.39 \times 25 \mathrm{~cm}$ ) of $0.20 \mathrm{mg}$ IA3 after chymotryptic digestion

For elution conditions see Figure 2. C. $(3,4,5)$ refer to the incomplete digest from res. 31 to res. 57 .

\subsection{Alignments of peptides and complete amino acid sequence of $\mathrm{I}^{\mathrm{A}} \mathbf{3}$}

The amino acid sequence determined from the cyanogen bromide peptides and the peptides from enzymatic digestion is shown in Figure 4.

The C-terminal sequence was only determined from the chymotryptic peptide C-6, and final identification of the C-terminal amino acid residue as glutamic acid rather than glutamine is still lacking.

The sequence of the inhibitor was confirmed from amino acid analysis of isolated chymotryptic peptides C-1, C-2 and C-6 (Figure 5 and Table II). Cleavage had as expected taken place at Phe-12, Phe-30, Tyr-53 and Tyr-57, but also to a certain extent at Met-33. The peak containing C-4 was a mixture of cleavage products from the sequence Phe- 30 to Tyr-57. Analyses of this peak through 7 steps of Edman degradation confirmed the established sequences from positions $31-37$ and $34-40$, respectively.

\subsection{Inhibition of proteinase $A$}

In order to localize the part of the inhibitor IA3 molecule essential for inhibition, activity 


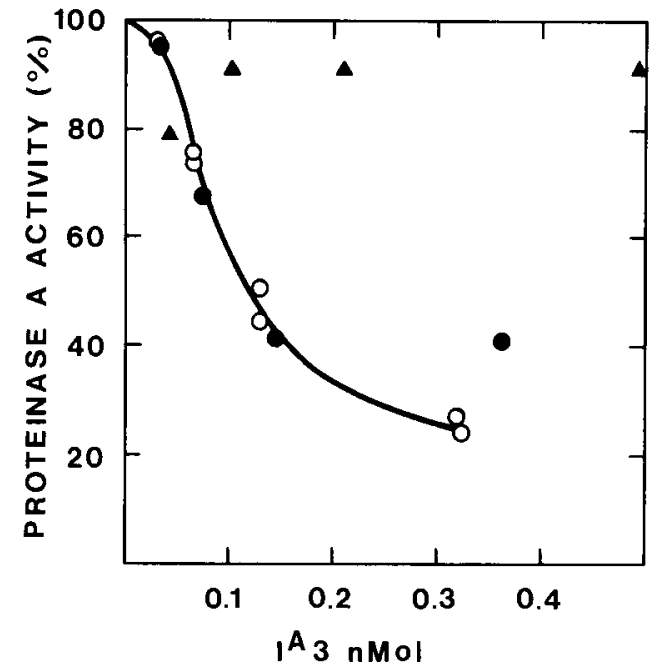

Figure 6. Inhibition of proteinase A.

An amount corresponding to $2.9 \mu \mathrm{g}$ proteinase $\mathrm{A}$ in the test solution, was inhibited with 10,25,50 and $125 \mu$ of a): an IA3 solution of $2.6 \mathrm{~nm}(\mathrm{O}) \mathrm{b}$ ): a solution of the isolated cyanogen bromide peptide F-2 of $2.9 \mathrm{nM}(\boldsymbol{O})$ and $\mathrm{c}$ ): a solution of the isolated peptide F-3 of 4.2 nM (A).

measurements of inhibitor IA 3 were compared to measurements using the cyanogen bromide fragments F-2 and F-3. As seen on Figure 6, F-2 inhibits proteinase A nearly as effective as the intact molecule while F-3 has essentially no effect. However, total loss of inhibitor activity was observed when $\mathrm{I}^{\mathrm{A}} 3$ was digested with either chymotrypsin or $\mathrm{S}$. aureus protease.

\section{DISCUSSION}

The proteinase A inhibitor from baker's yeast prepared in this study appears to be identical to IA3 previously isolated by NUNEZ DE CASTRO and Holzer (15) since the small differences in amino acid composition (Table I) most likely are explained from incomplete hydrolysis of the highly resistant Val-Val peptide bond at position 25-26. Similarly, the difference in isoelectric point of I $\mathrm{I}^{\mathrm{A}} 3$ determined by us to be 6.6 and by SAHEKI et al. (19) to be 6.3 may reflect use of different temperatures during the focusing or while the $\mathrm{pH}$ of the isolated fractions was measured.

When the isoelectric point is calculated from the sequence listed in Figure 4 and the pK values reported by TANFORD (23) a value of $\mathrm{pH} 6.5-6.6$ is found in agreement with our experimental value. Furthermore, it should be noted that a replacement of the $\mathrm{C}$-terminal glutamic acid residue with a glutamine residue would increase $\mathrm{pI}$ to a value above 7.5 and this is the basis for the residue assignment of Figure 4.

Due to blocking of the $\mathrm{N}$-terminal residue, IA3 had to be degraded to smaller fragments by a combination of chemical and enzymatic methods before the sequence could be determined. HPLC proved very efficient in the purification of the degradation products, such that the two cyanogen bromide fragments of similar size, F-2 and F-3, which could not be separated by gel chromatography were easily resolved by HPLC. Since the peptides should be free of salt before application to the sequencer cup, the triethylammonium phosphate of the HPLC buffer system had to be removed. This was done by addition of barium acetate and lyophilization, but this procedure, unfortunately, caused a loss of about $60 \%$ of the peptides, probably due to coprecipitation with the barium phosphate.

During the sequencing operations it was observed that only a fraction of the two peptides F-2 and C-6 with N-terminal asparagine residues reacted with PITC. It is conceivable that the acidic conditions of the HPLC isolation procedure has caused a partial $\alpha \rightarrow \beta$ shift of the asparagine peptide bonds as reported by EDMAN and Henschen (5) and thus decreased the amount of peptide available for reaction with PITC, especially since a similar drop in reactive $\mathrm{N}$-terminal asparagine residue was not observed in F-2 after gel filtration.

The two inhibitors of proteinase $\mathrm{B}, \mathrm{I}^{\mathrm{B}} \mathrm{I}$ and $I^{B} 2$, sequenced by MAIER et al. $(12,13)$ show a very high degree of homology. $\mathrm{I}^{\mathrm{A}} 3$ has approximately the same molecular weight as these two inhibitors and it also lacks disulfide bridges, but in spite of these similarities $I^{A} 3$ shows no sequence homology with the proteinase $B$ inhibitors.

The lack of disulfide bridges and the high content of polar amino acid residues indicate a flexible, perhaps randomly coiled, structure for $\mathrm{I}^{\mathrm{A}} 3$ as has been suggested by MUESSDOERFFER et al. (14) on basis of an abnormally high apparent molecular weight observed in gel filtration experiments with native $I^{\mathrm{A}} 3$. 
In an inhibitor with such a flexible structure, it might be expected that only a minor section of the molecule would be involved in the inhibitory function. This has been confirmed from our experiments which show that essentially all the inhibitor activity is preserved in the F-2 fragment of only 32 residues. Most likely, the activity resides in an even smaller fragment and further experiments are planned to verify this assumption.

\section{ACKNOWLEDGEMENTS}

We wish to thank Christina Casagli for her participation in the development of the HPLC technique for separating peptides. Two of us, $U$. M. and B. M., wish to thank the board of Carlsberg Laboratory for financial support. The excellent technical assistance of ms. BodiL Corneliussen, ms. Hanne Christiansen, and ms. LONE SøRENSEN is gratefully acknowledged.

\section{REFERENCES}

1. Austin, B. M. \& E. L. Smith: Action of staphylococcal proteinase on peptides of varying chain length and composition. Biochem. Biophys. Res. Commun. 72, 411-417 (1976)

2. Betz, H. H. Hinze \& H. Holzer: Isolation and properties of two inhibitors of proteinase $B$ from yeast. J. Biol. Chem. 249, 4515-4521 (1974)

3. Bunning, P. \& H. Holzer: Characteristics and biological functions of proteinase inhibitors from yeast. In: Limited proteolysis in microorganisms, G. N. Cohen \& H. Holzer eds. U.S. Department of health, education and welfare, $p$. $81-85$ (1978)

4. Edman, P. \& A. BegG: A protein sequenator. Eur. J. Biochem. I, 80-91 (1967)

5. Edman, P.\& A. Henschen: Sequence determination. In: Protein Sequence Determination. Molecular Biology Biochemistry and Biophysics 8 . 2nd ed., S. B. Needleman ed., Springer-Verlag, Berlin, Heidelberg and New York, pp. 232-279 (1975)

6. Gross, The cyanogen bromide reaction. In: Methods in enzymology, S. Colowick \& $\mathrm{N}$. Kaplan eds., Academic Press, New York, 11, 238-255 (1967)

7. Holzer, H.: The proteolytic system in yeast. In: Limited proteolysis in microorganisms, G. N. Cohen \& H. Holzer eds., U.S. Department of health, education and welfare, pp. 57-60 (1978)
8. Johansen, J, T., K. Breddam \& M. Ottesen: Isolation of carboxypeptidase $\mathrm{Y}$ by affinity chromatography. Carlsberg Res. Commun. 41, I-14 (1976)

9. Johansen, J. T., C. Overballe-Petersen, B. Martin, V. Hasemann \& I. Svendsen: The complete amino acid sequence of copper,zinc superoxide dismutase from Saccharomyces cerevisiae. Carlsberg Res. Commun. 44, 201-217 (1979)

10. Kulbe, K. D.: Rapid separation of phenylthiohydantoin (PTH) amino acids by thin-layer chromatography on polyamide glass plates. Anal. Biochem. 44, 548-558 (1971)

I1. Maler, K., H. Müller \& H. Holzer: Purification and molecular characterization of two inhibitors of yeast proteinase B. J. Biol. Chem. 254, 8491-8497 (1979)

12. Maier, H., H. Müller, R. Tesch, I. Witt \& H Hol.zer: Amino acid sequence of yeast proteinase B inhibitor 1. Comparison with inhibitor 2. Biochem. Biophys. Res. Commun. 91, 1390$1398(1979)$

13. Maier, K., H. Müllek, R. Tesch, I. Witt \& H HoI.zER: Primary structure of yeast proteinase B inhibitor 2. J. Biol. Chem. 254, 12555-12561 (1979)

14. Muessdoerffer, F., E.-G. Afting \& H. Holzer: Molecular weight and hydrodynamic properties of a proteinase A inhibitor from baker's yeast. Hoppe-Seyler's. Z. Physiol. Chem. 359, 993997 (1978)

15. Nunez de Castro, I. \& H. Holzer: Studies on the proteinase A inhibitor IA3 from yeast. Hoppe-Seyler's Z. Physiol. Chem. 357, 727-734 (1976)

16. Rivier, J. E.: Use of trialkyl ammonium phosphate (TAAP) buffers in reverse phase HPLC for high resolution and high recovery of peptides and proteins. J. Liq. Chem. 1, 343-366 (1978)

17. Saheki, T. \& H. Holzer: Comparisons of the tryptophan synthetase inactivating enzymes with proteinases from yeast. Eur. J. Biochem. 42. $621-626(1974)$

18. Saheki, T. \& H. Holzer: Proteolytic activities in yeast. Biochem. Biophys. Acta 384, 203-214 (1975)

19. Saheki, T., Y. Matsuda \& H. Holzer: Purification and characterization of macromolecular inhibitors of proteinase A from yeast. Eur. J. Biochem. 47, 325-332 (1974)

20. Sheeman, J. C. \& D.-D. H. Yang: The use of Nformylamino acids in peptide synthesis. J. Am. Chem. Soc. $80,1154-1158$ (1958) 
21. Swank, R. T. \& K. D. Munkres: Molecular weight analysis of oligopeptides by electrophoresis in polyacrylamide gel with sodium dodecyl sulfate. Anal. Biochem. 39, 462-477 (1971)

22. Svenosen, I., B. Martin \& I. Jonassen: Characteristics of Hiproly barley III. Amino acid sequences of two lysine-rich proteins. Carlsberg Res. Commun. 45, 79-85 (1980)

23. TANFORD, C: Hydrogen ion titration curves of protein. Protein Chemistry, 17, 69-165 (1962)
24. Winter, A. \& C. Kari.sson: Preparative electrofocusing in density gradients. LKB application note 219 (1976)

25. Winter, A. H. Perlmutter \& H. Davis: Preparative flat-bed electrofocusing in a granulated gel with the LKB 2117 multiphor. LKB application note 198 (1975)

26. Wrigley, C.: Gel electrofocusing. In: Methods in Enzymology, S. Colowick \& N. Kaplan eds. Academic Press, New York. 22, 559-564 (1971) 